in vivo $35: 2991-3000(2021)$

doi:10.21873/invivo.12594

Review

\title{
Adaptive Membrane Fluidity Modulation: A Feedback Regulated Homeostatic System Hiding in Plain Sight
}

\author{
ELZBIETA IZBICKA* and ROBERT T. STREEPER*
}

\author{
New Frontier Labs LLC, San Antonio, TX, U.S.A.
}

\begin{abstract}
The structure of the plasma membrane affects its function. Changes in membrane fluidity with concomitant effects on membrane protein activities and cellular communication often accompany the transition from a healthy to a diseased state. Although deliberate modulation of membrane fluidity with drugs has not been exploited to date, the latest data suggest the "druggability" of the membrane. Azelaic acid esters (azelates) modulate plasma membrane fluidity and exhibit a broad range of immunomodulatory effects in vitro and in vivo. Azelates represent a new class of drugs, membrane active immunomodulators (MAIMs), which use the entire plasma membrane as the target, altering the dynamics of an innate feedback regulated homeostatic system, adaptive membrane fluidity modulation (AMFM). A review of the literature data spanning $>200$ years supports the notion that molecules in the MAIMs category including known drugs do exert immunomodulatory effects that have been either neglected or dismissed as off-target effects.
\end{abstract}

A literature search was conducted using PUBMED, MEDLINE, and Library of Congress databases to capture peer-reviewed research articles (including reviews and metaanalyses), published through August 27, 2021, with the

This article is freely accessible online.

*Both Authors contributed equally to this study.

Correspondence to: Elzbieta Izbicka, New Frontier Labs LLC, 900 NE Loop 410, suite D-119, San Antonio, Texas, U.S.A. Tel: +1 2107256868, e-mail: eizbicka.g4@gmail.com

Key Words: Plasma membrane, fluidity, azelaic acid ester, azelate, homeostasis, review. earliest record dating from 1801. The search terms included "plasma membrane" AND "fluidity" OR "plasticity" OR "rigidity". Secondary searches combined keywords consisting of individual chemical entities listed in this manuscript (for example, cholesterol, ethanol, turpentine) and physiological conditions (for example pain, fever, disease). The collected abstracts and/or full papers were surveyed by both authors in order to confirm article relevancy to the topic.

\section{Plasma Membrane at the Crossroads of Communication in Health and Disease}

The plasma membrane of eukaryotic cells plays an active role in the flow of information between cells and their environment $(1,2)$. Variations in the composition of membrane lipids affect the membrane fluidity and membrane environment has an impact on integral and membraneassociated proteins with consequences for the entire organism (3-6). In transition from a healthy to a diseased state, cellular plasma membranes usually become more rigid $(5,7,8)$ mainly due to incorporation of cholesterol (9) that is dynamically exchanged between the blood and plasma membranes $(9,10)$. High blood cholesterol correlates with various diseases (11-14) while positive health effects can be achieved upon lowering cholesterol content of the plasma membrane (15-17).

Structural changes in cellular plasma membranes have been mainly focused on the role of membrane structural integrity "in sickness and health" (18, 19), although membrane domains were also proposed as possible drug targets (20). Intentional pharmacological tuning of membrane fluidity with drugs has received little attention but on closer examination there is a significant amount of data suggesting the "druggability" of the fluidity of cell membranes. The hypothesis that one can affect the activities 
of membrane-associated proteins through alterations in plasma membrane fluidity using lipid-soluble molecules with application in the treatment of human and animal diseases is supported by our experimental data on the effects of esters of azelaic acid (azelates) that act as membrane fluidizers and exert immunomodulatory effects in vitro and in vivo $(1,21$ 23). Unlike targeted therapies that usually focus on single molecular entities, the target for azelates is the entire plasma membrane. Azelates have been recognized as the first representatives of a novel class of drugs, membrane active immunomodulators (MAIMs) (1).

\section{MAIMs and Adaptive Membrane Fluidity Modulation (AMFM)}

This concept built upon experimental data has been described elsewhere (1) and is briefly summarized below. We postulated that MAIMs change plasma membrane fluidity and that membrane fluidity is homeostatically controlled via an innate feedback mechanism, Adaptive Membrane Fluidity Modulation (AMFM), an active process of plasma membrane fluidity regulation in mammalian cells. Our AMFM hypothesis expands and extends the historical concept of homeoviscous adaptation (24) and proposes a mechanism directed to the regulation of biochemical processes driven by the physiological modulation of plasma membrane fluidity.

The temperature of the human body, and those of all warm-blooded animals outside of hibernation, is regulated in a narrow temperature range. For humans the normal body temperature is around $36.6^{\circ} \mathrm{C}$. Body temperature varies in pathologic states between $35^{\circ} \mathrm{C}$ (hypothermia) and high fever at around $42^{\circ} \mathrm{C}$. We propose that body temperature control is essential to maintaining cellular plasma membrane fluidity and thus membrane protein function. What, one must ask, is the "purpose" of fever. That is to say, what survival advantage does the ability to mount a fever confer? Most pathogens are unaffected by the modest temperatures attained in human fever despite superstitious beliefs that fever was somehow involved in killing them. We propose that fever may be directed to regulating inflammatory mediator trafficking. Everyone who has had a fever has also had the experience of the fever" breaking" with subsequent resolution of the hyperthermic state and improvement in subjective feelings of wellbeing. The AMFM hypothesis sheds a new light on these innate processes, on targeted therapies and receptor-directed mechanisms of action of hormones, drugs and toxins (1).

\section{MAIMs Hiding in Plain Sight}

A review of the biomedical literature related to the modulation of plasma membrane published over the past two hundred years has led us to the conclusion that many known drugs, natural products, and synthetic molecules have membrane fluidity modulating properties and can be viewed, at least in part, as MAIMs. The biochemical effects of these MAIMs have been well documented in the medical literature but the underlying AMFM system on which they exert their effects has remained largely unappreciated. We have grouped these molecules into three broad categories: drugs, natural products, and synthetic molecules. We further discuss representative molecules in each category in the light of their membrane modulatory activities.

There are numerous examples of drugs, many of them derived from natural sources, that are also MAIMs. For example, the fatty acid azelaic acid has been used in the treatment of dermatological diseases for decades $(25,26)$. Diethyl azelate, a natural product made by plants and animals and unwittingly used by humanity over many millennia (27-34), is also a promising drug candidate (21).

Tecfidera (dimethyl fumarate) was first used in the treatment of psoriasis and has been repurposed for the treatment of multiple sclerosis (35) but its mechanism of action of remains unclear. Dimethyl fumarate is known to have immunomodulatory properties (36) and most of the affected targets have antioxidant and/or anti-inflammatory functions (37). Tecfidera is used in the clinic at doses of hundreds of milligrams per day. In addition, the drug is an allergic sensitizer at low picomolar levels (38).

Ethanol is natural product and also a drug. Human consumption of ethanol rendered from wheat in the form of beer dates back at least 10,000 years (39). The date that humans recognized the pharmacological effects of ethanol intake is lost to history. The medical community has reported on its effects starting as early as 1805 and continuing through the present day (40-42). Ethanol has no known receptor, is a membrane fluidizer at low doses (43) and displays a non-monotonic effect on lipid chain order in a striking contrast to methanol $(44,45)$. Ethanol is known to modulate the activity of GABA A receptors, glycine receptors and two pore potassium channels (46).

The organosulfur compound dimethyl sulfoxide (DMSO) enhances the cell membrane penetration of drugs or DNA and enhances percutaneous absorption when used in combination with other substances. In vitro data supported by molecular dynamics simulations suggest that increasing concentrations of DMSO induce membrane undulation and thinning, followed by pore formation and eventually bilayer collapse (47). DMSO can also provide a rapid albeit temporary relief of arthritic pain (48) and has some utility in wound healing (49).

General anesthetics such as isoflurane, propofol, phencyclidine, and noble gases (Xe, He) also lack known receptors and behave in a manner similar to ethanol $(37,44$, 50-52). Ether, the oldest general anesthetic, was first reported in 1851 to induce glucosuria (53). It was thought at the time 
that the nervous system or emotional factors were responsible for these observations (54). Plasma membrane involvement was highlighted by a report on the effect of isoflurane on vesicle exocytosis and calcium channels (55). Direct demonstration of targeting of plasma membrane lipids by inhalational of anesthetics led to the proposal of a mechanism that involves disruption of lipid rafts (56).

Antibiotics, such as tetracyclines, cross the plasma membrane and their activity is related to transmembrane flux (57). Tetracyclines are also known to act by interfering with protein synthesis at the ribosome by inhibiting attachment of the aminoacyl-tRNA to the A site. Thus, tetracycline mode of action encompasses a defined protein target and a membrane modulatory mechanism. The anticonvulsant, phenytoin, causes voltage-dependent block of voltage gated sodium channels (58). Hexamethylene bisacetamide, a differentiating agent, is an amphipathic molecule that perturbs membrane-protein interactions and segregates lipids in discrete domains (59).

Decamethonium bromide, a muscle relaxant, is a membrane depolarizer (60) that interacts with plasma membrane components through hydrophobic interactions, Van der Waals forces, and ion pairing. Phospholipid drugs exemplified by miltefosine, edelfisone, and perifosine displace proton pump protein from lipid rafts and alter cholesterol trafficking (61-63).

The activities of many drugs can be accounted for more fully by inclusion of both target/receptor mediated activity and MAIM activity. For example, the histone deacetylase inhibitors suberoylanilide hydroxamic acid and valproic acid affect expression of plasma membrane receptors and also display membrane disordering activity $(45,64)$.

Aspirin, a pharmacological Swiss army knife, exerts a wide range of effects ranging from analgesic, antipyretic and antiinflammatory activities, cardiovascular benefits, to cancer prevention (65). According to the commonly accepted mechanism of action, aspirin inhibits cyclooxygenase (66). A small human study using high doses of aspirin reportedly improved glucose tolerance and lowered insulin resistance and the clinical activity of aspirin was explained in terms of specific inhibition of the serine/threonine kinase cascade (67). Yet proposed mechanisms of action do not convincingly explain the breadth of known effects of aspirin. Since aspirin increases plasma membrane fluidity and prevents formation of lipid rafts through non-specific interactions with lipid membranes (68), we propose that aspirin functions as a MAIM and thus shares similar features with diethyl azelate (DEA). An immunomodulatory activity of aspirin was postulated in the past (69) but the concept has not gained much attention.

The second category of MAIMs encompasses natural products, many of which are used as drugs. Our observations of the immunomodulatory activities of azelates are echoed in the biological activities of some natural products.
Polyunsaturated fatty acids such as omega-3 and omega-6 fatty acids affect membrane fluidity when incorporated into phospholipids (70). Direct binding of omega-3 fatty acids to the cellular receptor FFA4 changes calcium influx across the plasma membrane (71). Trans fatty acids incorporate into lipid rafts and can induce tumor growth in some cases (72). Medical uses of turpentine oil composed of terpenes obtained by the distillation of pine resin were reported in the early $19^{\text {th }}$ century $(73,74)$. Terpenes are also known to transiently affect cellular signaling (75).

Carotenoid pigments increase plasma membrane rigidity in Staphylococcus aureus (76). Exogenous carotenoids have beneficial effects in human disease prevention (77). Most polar carotenoids span the lipid bilayer, rigidify the membranes and limit oxygen penetration to the hydrophobic membrane core susceptible to oxidative degradation (78). Natural polyphenols produced in plants as secondary metabolites, are a large part of the human diet (79) and have pharmacological properties that include anti-coronavirus and immunomodulatory activities (80). The most abundant polyphenols such as flavonoids inhibit plasma membrane ATPase and maintain ion cellular homeostasis (81). A review of plant-derived immunomodulators with immunosuppressive properties was focused on their potential to calm the cytokine storm (82), presumably due to membrane interactions. For example, luteolin intercalates within cell membranes leading to their disruption (83). Resveratrol, a natural phenol, apparently targets the entire cell membrane and affects the intramembrane ion transport (84). Curcumin, another well-known polyphenol, has membrane-thinning properties (85), decreases membrane rigidity but drastically stiffens the bilayers in model membranes with high cholesterol content (86). Curcumin modulates the function and expression of structurally and functionally unrelated membrane proteins (87).

The third category of MAIMs is represented by amphiphilic synthetic molecules that often contain halogens. Organic halogen compounds are a large class of chemicals that contain one or more halogens (fluorine, chlorine, bromine, or iodine) combined with carbon and other elements. Notorious polyfluorinated compounds such as perfluorooctane sulfonate (PFOS) and perfluorooctanoic acid (PFOA) are persistent in the environment and have been shown to cause membrane disruption and oxidative damage in model systems (88). Some halogenated organics are endocrine disruptors that can interfere with endocrine systems (89). Most toxicants, including endocrine disruptors, have a U-shaped dose response curve. This type of dose response, known as hormesis (90), defies the toxicological dogma of "the dose makes the poison". For example, endocrine disruptors can have effects at low doses that are not predicted by effects at higher doses (91). There are important toxicological implications of the AMFM hypothesis. The endocrine disruptors are biologically persistent due to their poor metabolism and slow elimination. They are associated with diseases characterized by 
derangement of innate and adaptive immunity in those primarily exposed and their offspring (92). The environmental impact of these "bad MAIMs", or shall we say, "forever MAIMs," is underappreciated. As the list is very long, we will highlight just a few notorious examples.

The fungicide vinclozolin binds to membrane androgen receptor (93). Organophosphate pesticides have been shown to decrease erythrocyte membrane fluidity (94). Dioxins (e.g. Agent Orange) contain 2,3,7,8-tetrachlorodibenzo-p-dioxin (TCDD) that alters plasma membrane function (95). In fact, dioxin insult may induce azelate levels (28), an effect that can be viewed as a chemoprotective response of endogenously produced azelate. The industrial surfactant perfluorooctanoic acid is present in many household products including stainresistant carpets, microwave popcorn bags, and dental floss. Perfluorooctanoic acid causes irreversible plasma membrane injury in acute exposure (96), is present in the blood of $98 \%$ of the US population, and is linked to increased cancer rates (97). Commonly used bisphenol plasticizers alter calcium cellular entry in a non-monotonic manner (98). Bisphenol A acts as a selective estrogen receptor modulator and initiates rapid responses via estrogen receptors presumably associated with the plasma membrane (99). Most humans are exposed to phthalate plasticizers with adverse effects on human reproduction (100). Dimethyl phthalate has been shown to directly damage bacterial cell walls (101).

\section{Physiological Support for the AMFM Hypothesis}

The AMFM hypothesis is supported by a wealth of observations of physiological processes. Fever is probably the most obvious case. The role of fever was queried in 1805 (102) and a report on the effect of acute fever on glycosuria appeared in 1885 (103). The peri-ovulation body temperature spike is well known (104) but its mechanism, and purpose, is not well understood though the fact that fertilization involves the fusion of the sperm with the egg suggests the possibility that the temperature spike may facilitate the process. It is not surprising that elevated temperature increases membrane fluidity thus when body temperature increases during a high fever, the fluidity of cell plasma membranes also increases. As a result, proteins and other membrane components become more mobile within and through the membrane.

The role of fever in higher organisms is thought to disfavor pathogen survival in hosts as diverse as locusts, snails, finches, iguanas, rabbits and humans $(105,106)$. Colloquially, many laymen and even numerous scientists and physicians labor under the tragically flawed idea that the purpose of fever is to kill pathogens. However, a growing body of evidence supports the idea that fever confers a survival advantage in the form of disease tolerance to host animals.

Additional illustration of the AMFM action include fluctuations of blood glucose, insulin, and lipids under normal physiological conditions or in the response to infections or drugs. Examples include increased triglyceride levels and insulin resistance in pregnancy $(107,108)$, high triglyceride levels associated with multiple diseases (109), and diabetogenic effects of statin therapy (110). The association of obesity with dyslipidemia and insulin resistance is well documented $(111,112)$ but a less known consequence of obesity may be hampering immune responses to SARS-CoV-2 vaccine (113).

A recent report on cholesterol metabolites that facilitate innate immunity to bacterial infections by mobilizing cell surface accessible cholesterol sheds a new light on the feedback loop involving a signal-mediated membrane remodeling pathway (114). The implications of this finding go far beyond the cellular response to bacterial pathogens. Cholesterol has also been shown to affect the function of some G protein-coupled receptors (GPCRs) (115), the largest family of integral membrane proteins involved in cellular signal transduction. A molecular sensor for cholesterol in a human GPCR has recently been identified (116) supporting the notion of a direct relationship between membrane lipids, proteins, and cellular signaling.

Since anesthesia directly affects plasma membrane fluidity, it is quite interesting that anesthesia by itself or in association with surgical procedures can lead to rapid adaptive changes in blood glucose, insulin, and lipids. In rodents, plasma glucose and insulin increase in response to anesthesia in the absence of surgical stress (117). In human studies, hyperinsulinemic and normoglycemic clamp after heart surgery caused elevation of blood lipids (118). Shortterm propofol anesthesia significantly raised triglyceride levels in pediatric patients (119). Elevated risk for perioperative hyperglycemia observed in non-diabetic subjects but not in diabetic patients (120) was referred to as paradoxical. For us the effect is akin to improved control of glucose by DEA in subjects with higher levels of hemoglobin A1c (21).

"Forever MAIMs" also affect lipid and glucose levels. Exposure to perfluoroalkyl substances PFOAs increases the risk for insulin resistance and type 2 diabetes, and disrupts lipid and weight regulation $(121,122)$. Dioxins such as TCCD alter lipid metabolism in rodents (123). Human epidemiologic studies suggested elevated risk of type 2 diabetes and an increase of its hallmark, insulin resistance (124).

Other supportive evidence comes from documented effects of diet on human health. Increased incidence of diabetes, heart disease and cancer are associated with excessive ethanol intake, while health benefits of Asian diet with fermented soy, Mediterranean diet with wine and olive oil, and other dietary fats such as fish and vegetable oils are widely acknowledged. Observations on the efficacy of olive oil for preventing and curing the plague were reported in 1801 (125). 


\section{It Is About Time. The First Minutes of MAIMs Action}

As presented above, physiological effects of MAIMs on cellular signaling through the adaptive feedback response in the form of transcriptional, translational and post-translational events happen on the time scale of hours to days. In contrast, local membrane effects of MAIMs translate to acute systemic responses that can be observed within minutes.

Inhalational anesthetics exert their effects in less than 5 min (126). For orally administered MAIMs, either drugs or foods, the timing can be equally short. Low nanomolar doses of nitroglycerin cause immediate decrease in the mean diastolic blood pressure in rats, and a single sublingual dose of nitroglycerin affects hemodynamic parameters in humans in 2-5 min (127). The effects are consistent with rapid absorption of nitrates from mucous membranes, the gastrointestinal tract, and the skin (128). Regional effects of ethanol intoxication manifested as cerebral blood flow effects are observed in 5 min (129). DMSO applied topically quickly causes a distinctive garlic taste on the tongue that is indicative of a speedy transport through skin and mucosa (130). Resveratrol which apparently uses the entire membrane as the target (84), used in a lozenge formulation for oral transmucosal delivery reached maximum plasma concentration in $15 \mathrm{~min}$ (131). Significant changes in flowmediated dilation are seen in 30 minutes of grape polyphenol supplementation (132). Given that it takes blood 20 seconds to circulate through the whole body (133), a single dose of an oral MAIM can rapidly achieve systemic effects.

\section{Concluding Remarks}

The AMFM hypothesis does not account for the receptor or molecular target mediated activities of these compounds but it provides insight to the source of those activities that are not accounted for by receptor or specific target effects. Our understanding of the AMFM system opens the door to developing novel treatments for diseases including diabetes, cardiovascular, infectious and autoimmune diseases, stroke, cancer, biodefense indications and many others. AMFM is likely to be a valuable addition and/or complement to the current targeted therapies and receptor-directed mechanisms of action of hormones, drugs and toxins.

\section{Conflicts of Interest}

EI and RTS are the owners and officers of New Frontier Labs, LLC.

\section{Authors' Contributions}

EI and RTS formulated the theoretical concepts based on own research data, performed literature searches, and wrote the manuscript.

\section{Acknowledgements}

The Authors are indebted to their long-time, now deceased collaborator, Tadeusz Izbicki, M.D, Ph.D., for his medical advice, insightful comments, and philosophical discussions that added value to their studies. The Authors are also grateful to Richard Luduena $\mathrm{PhD}$, for his review of the manuscript and helpful comments.

\section{References}

1 Izbicka E, Streeper R and Louden C: Adaptive membrane fluidity modulation: A feedback regulated homeostatic system and target for pharmacological intervention. In Vivo 35(6) in press, 2021.

2 Grecco HE, Schmick M and Bastiaens PI: Signaling from the living plasma membrane. Cell 144(6): 897-909, 2011. PMID: 21414482. DOI: 10.1016/j.cell.2011.01.029

3 Fessler MB and Parks JS: Intracellular lipid flux and membrane microdomains as organizing principles in inflammatory cell signaling. J Immunol 187(4): 1529-1535, 2011. PMID: 21810617. DOI: $10.4049 /$ jimmunol.1100253

4 Cooper RA: Abnormalities of cell-membrane fluidity in the pathogenesis of disease. N Engl J Med 297(7): 371-377, 1977. PMID: 327326. DOI: 10.1056/NEJM197708182970707

5 Desai AJ and Miller LJ: Changes in the plasma membrane in metabolic disease: impact of the membrane environment on $\mathrm{G}$ protein-coupled receptor structure and function. Br J Pharmacol 175(21): 4009-4025, 2018. PMID: 28691227. DOI: 10.1111/ bph.13943

6 Schoeniger A, Adolph S, Fuhrmann H and Schumann J: The impact of membrane lipid composition on macrophage activation in the immune defense against Rhodococcus equi and Pseudomonas aeruginosa. Int J Mol Sci 12(11): 7510-7528, 2011. PMID: 22174614. DOI: 10.3390/ijms12117510

7 Pilon M: Revisiting the membrane-centric view of diabetes. Lipids Health Dis 15(1): 167, 2016. PMID: 27671740. DOI: 10.1186/s12944-016-0342-0

8 Owen DM, Williamson DJ, Magenau A and Gaus K: Subresolution lipid domains exist in the plasma membrane and regulate protein diffusion and distribution. Nat Commun 3: 1256, 2012. PMID: 23212385. DOI: $10.1038 /$ ncomms 2273

9 Cooper RA: Influence of increased membrane cholesterol on membrane fluidity and cell function in human red blood cells. J Supramol Struct 8(4): 413-430, 1978. PMID: 723275. DOI: $10.1002 /$ jss 400080404

10 Malhotra S and Kritchevsky D: Cholesterol exchange between the red blood cells and plasma of young and old rats. Mech Ageing Dev 4(2): 137-145, 1975. PMID: 1152545. DOI: 10.1016/0047-6374(75)90015-9

11 Owen JS, Bruckdorfer KR, Day RC and McIntyre N: Decreased erythrocyte membrane fluidity and altered lipid composition in human liver disease. J Lipid Res 23(1): 124-132, 1982. PMID: 7057101 .

12 Kojima K: Molecular aspects of the plasma membrane in tumor cells. Nagoya J Med Sci 56(1-4): 1-18, 1993. PMID: 7898547.

13 Tokumasu F, Ostera GR, Amaratunga C and Fairhurst RM: Modifications in erythrocyte membrane zeta potential by Plasmodium falciparum infection. Exp Parasitol 131(2): 245-251, 2012. PMID: 22459624. DOI: 10.1016/j.exppara.2012.03.005

14 Kopecka J, Trouillas P, Gašparović AČ, Gazzano E, Assaraf YG and Riganti C: Phospholipids and cholesterol: Inducers of cancer 
multidrug resistance and therapeutic targets. Drug Resist Updat 49: 100670, 2020. PMID: 31846838. DOI: 10.1016/j.drup. 2019.100670

15 Arispe N and Doh M: Plasma membrane cholesterol controls the cytotoxicity of Alzheimer's disease AbetaP (1-40) and (1-42) peptides. FASEB J 16(12): 1526-1536, 2002. PMID: 12374775. DOI: $10.1096 / \mathrm{fj} .02-0829 \mathrm{com}$

16 Goluszko P and Nowicki B: Membrane cholesterol: a crucial molecule affecting interactions of microbial pathogens with mammalian cells. Infect Immun 73(12): 7791-7796, 2005. PMID: 16299268. DOI: 10.1128/IAI.73.12.7791-7796.2005

17 Wang SS, Rymer DL and Good TA: Reduction in cholesterol and sialic acid content protects cells from the toxic effects of betaamyloid peptides. J Biol Chem 276(45): 42027-42034, 2001. PMID: 11557751. DOI: 10.1074/jbc.M102834200

18 Ammendolia DA, Bement WM and Brumell JH: Plasma membrane integrity: implications for health and disease. BMC Biol 19(1): 71, 2021. PMID: 33849525. DOI: 10.1186/s12915021-00972-y

19 Dias C and Nylandsted J: Plasma membrane integrity in health and disease: significance and therapeutic potential. Cell Discov 7(1): 4, 2021. PMID: 33462191. DOI: 10.1038/s41421-02000233-2

20 van Spriel $A B$, van den Bogaart $G$ and Cambi A: Editorial: Membrane domains as new drug targets. Front Physiol 6: 172, 2015. PMID: 26082723. DOI: 10.3389/fphys.2015.00172

21 Streeper RT, Louden C and Izbicka E: Oral azelaic acid ester decreases markers of insulin resistance in overweight human male subjects. In Vivo 34(3): 1173-1186, 2020. PMID: 32354907. DOI: 10.21873 /invivo. 11890

22 Streeper RT, Izbicka E, inventors; New Frontier Labs, LLC, assignee. Azelaic acid esters in the treatment of insulin resistance. USA patent US 10,251,857 B2, 2019.

23 Streeper RT, Izbicka E, inventors; New Frontier Labs LLC, assignee. Azelaic acid esters in the treatment or prevention of dyslipidemia and associated conditions. USA patent application US 2021/0251939 A1, 2021.

24 Sinensky M: Homeoviscous adaptation - a homeostatic process that regulates the viscosity of membrane lipids in Escherichia coli. Proc Natl Acad Sci USA 71(2): 522-525, 1974. PMID: 4360948. DOI: 10.1073/pnas.71.2.522

25 Lowe NJ: New approaches in dermatology: a clinical profile of azelaic acid. Cutis 57(1 Suppl): 7, 1996. PMID: 8654130.

26 Fitton A and Goa KL: Azelaic acid. A review of its pharmacological properties and therapeutic efficacy in acne and hyperpigmentary skin disorders. Drugs 41(5): 780-798, 1991. PMID: 1712709. DOI: 10.2165/00003495-199141050-00007

27 Smilowitz JT, O’Sullivan A, Barile D, German JB, Lönnerdal B and Slupsky CM: The human milk metabolome reveals diverse oligosaccharide profiles. J Nutr 143(11): 1709-1718, 2013. PMID: 24027187. DOI: 10.3945/jn.113.178772

28 Matsubara T, Tanaka N, Krausz KW, Manna SK, Kang DW, Anderson ER, Luecke H, Patterson AD, Shah YM and Gonzalez FJ: Metabolomics identifies an inflammatory cascade involved in dioxin- and diet-induced steatohepatitis. Cell Metab 16(5): 634-644, 2012. PMID: 23140643. DOI: 10.1016/j.cmet.2012. 10.006

29 Fan H, Fan W and Xu Y: Characterization of key odorants in Chinese chixiang aroma-type liquor by gas chromatographyolfactometry, quantitative measurements, aroma recombination, and omission studies. J Agric Food Chem 63(14): 3660-3668, 2015. PMID: 25797496. DOI: 10.1021/jf506238f

30 Saerens SM, Delvaux F, Verstrepen KJ, Van Dijck P, Thevelein JM and Delvaux FR: Parameters affecting ethyl ester production by Saccharomyces cerevisiae during fermentation. Appl Environ Microbiol 74(2): 454-461, 2008. PMID: 17993562. DOI: 10.1128/AEM.01616-07

31 Kostelenos G and Kiritsakis A: Olive tree history and evolution. In: Olives and olive oil as functional foods. Kiritsakis A and Shahidi F (eds.). Oxford, UK, John Wiley \& Sons Ltd, pp. 1-12, 2017.

32 Rahmani M: Food hazards and quality control in table olive processing with a special reference to functional compounds. In: Olives and olive oil as functional foods. Kiritsakis A and Shahidi F (eds.). Oxford, UK, John Wiley \& Sons Ltd, pp. 347-352, 2017.

33 Hymowitz T: The history of the soybean. In: Soy beans chemistry, production, processing and utilization. AOCS Press, pp. 1-31, 2008.

34 Kwon DY, Daily JW 3rd, Kim HJ and Park S: Antidiabetic effects of fermented soybean products on type 2 diabetes. Nutr Res 30(1): 1-13, 2010. PMID: 20116654. DOI: 10.1016/ j.nutres.2009.11.004

35 Venci JV and Gandhi MA: Dimethyl fumarate (Tecfidera): a new oral agent for multiple sclerosis. Ann Pharmacother 47(12): 1697-1702, 2013. PMID: 24259625. DOI: 10.1177/106 0028013509232

36 Mills EA, Ogrodnik MA, Plave A and Mao-Draayer Y: Emerging understanding of the mechanism of action for dimethyl fumarate in the treatment of multiple sclerosis. Front Neurol 9: 5, 2018. PMID: 29410647. DOI: 10.3389/fneur.2018.00005

37 Herring BE, Xie Z, Marks J and Fox AP: Isoflurane inhibits the neurotransmitter release machinery. J Neurophysiol 102(2): 12651273, 2009. PMID: 19515956. DOI: 10.1152/jn.00252.2009

38 Rantanen T: The cause of the Chinese sofa/chair dermatitis epidemic is likely to be contact allergy to dimethylfumarate, a novel potent contact sensitizer. Br J Dermatol 159(1): 218-221, 2008. PMID: 18503603. DOI: 10.1111/j.1365-2133.2008.08622.x

39 Dietrich O, Heun M, Notroff J, Schmidt K and Zarnkow M: The role of cult and feasting in the emergence of Neolithic communities. New evidence from Göbekli Tepe, south-eastern Turkey. Antiquity 86(333): 674-695, 2020. DOI: 10.1017/S0003598X00047840

40 Thomas W: On glycosuria. Br Med J 2(1301): 1053-1054, 1885.

41 Dickinson WH: On the morbid effects of alcohol, as shown in persons who trade in liquor. Med Chir Trans 56: 27-59, 1873. PMID: 20896410. DOI: 10.1177/095952877305600104

42 Trotter T: An Essay: Medical, philosophical, and chemical, on drunkenness, and its effects on the human body. Edinb Med Surgery J 1(1): 73-81, 1805.

43 Goldstein DB: Effect of alcohol on cellular membranes. Ann Emerg Med 15(9): 1013-1018, 1986. PMID: 3526990. DOI: 10.1016/s0196-0644(86)80120-2

44 Patra M, Salonen E, Terama E, Vattulainen I, Faller R, Lee BW, Holopainen $\mathrm{J}$ and Karttunen M: Under the influence of alcohol: the effect of ethanol and methanol on lipid bilayers. Biophys J 90(4): 1121-1135, 2006. PMID: 16326895. DOI: 10.1529/ biophysj.105.062364

45 Perlman BJ and Goldstein DB: Genetic influences on the central nervous system depressant and membrane-disordering actions of ethanol and sodium valproate. Mol Pharmacol 26(3): 547-552, 1984. PMID: 6092902. 
46 Goodman LS, Gilman A, Brunton LL, Lazo JS and Parker KL: Goodman \& Gilman's The pharmacological basis of therapeutics. 11th edn. New York, McGraw-Hill, 2006.

47 de Ménorval MA, Mir LM, Fernández ML and Reigada R: Effects of dimethyl sulfoxide in cholesterol-containing lipid membranes: a comparative study of experiments in silico and with cells. PLoS One 7(7): e41733, 2012. PMID: 22848583. DOI: 10.1371/journal.pone.0041733

48 Swanson BN: Medical use of dimethyl sulfoxide (DMSO). Rev Clin Basic Pharm 5(1-2): 1-33, 1985. PMID: 3916302.

49 Capriotti K and Capriotti JA: Dimethyl sulfoxide: history, chemistry, and clinical utility in dermatology. J Clin Aesthet Dermatol 5(9): 24-26, 2012. PMID: 23050031.

50 Lopez MM and Kosk-Kosicka D: Entropy-driven interactions of anesthetics with membrane proteins. Biochemistry 36(29): 88648872, 1997. PMID: 9220973. DOI: 10.1021/bi970028w

51 DePietro FR and Byrd JC: Effects of membrane fluidity on [3H]TCP binding to PCP receptors. J Mol Neurosci 2(1): 45-52, 1990. PMID: 2175211. DOI: 10.1007/BF02896925

52 Franks JJ, Horn JL, Janicki PK and Singh G: Halothane, isoflurane, xenon, and nitrous oxide inhibit calcium ATPase pump activity in rat brain synaptic plasma membranes. Anesthesiology 82(1): 108-117, 1995. PMID: 7832292. DOI: 10.1097/00000542-199501000-00015

53 Reynoso A: On the presence of sugar in urine. British and Foreign Medico-chirurgical Review 11, 1851.

54 Mellanby J: The influence of the nervous system on glycaemia and glycosuria. J Physiol 53(1-2): 1-16, 1919. PMID: 16993432. DOI: 10.1113/jphysiol.1919.sp001856

55 Wang HY, Eguchi K, Yamashita T and Takahashi T: Frequencydependent block of excitatory neurotransmission by isoflurane via dual presynaptic mechanisms. J Neurosci 40(21): 4103-4115, 2020. PMID: 32327530. DOI: 10.1523/JNEUROSCI.294619.2020

56 Pavel MA, Petersen EN, Wang H, Lerner RA and Hansen SB: Studies on the mechanism of general anesthesia. Proc Natl Acad Sci USA 117(24): 13757-13766, 2020. PMID: 32467161. DOI: $10.1073 /$ pnas. 2004259117

57 Gabler WL: Fluxes and accumulation of tetracyclines by human blood cells. Res Commun Chem Pathol Pharmacol 72(1): 39-51, 1991. PMID: 2052748.

58 Rogawski MA and Löscher W: The neurobiology of antiepileptic drugs. Nat Rev Neurosci 5(7): 553-564, 2004. PMID: 15208697. DOI: $10.1038 / \mathrm{nrn} 1430$

59 Escriba PV, Morales P and Smith A: Membrane phospholipid reorganization differentially regulates metallothionein and heme oxygenase by heme-hemopexin. DNA Cell Biol 21(4): 355-364, 2002. PMID: 12042074. DOI: 10.1089/104454902753759762

60 Lee $\mathrm{C}$ and Jones T: Molecular conformation-activity relationship of decamethonium congeners. Br J Anaesth 88(5): 692-699, 2002. PMID: 12067008. DOI: 10.1093/bja/88.5.692

61 Cuesta-Marbán Á, Botet J, Czyz O, Cacharro LM, Gajate C, Hornillos V, Delgado J, Zhang H, Amat-Guerri F, Acuña AU, McMaster CR, Revuelta JL, Zaremberg V and Mollinedo F: Drug uptake, lipid rafts, and vesicle trafficking modulate resistance to an anticancer lysophosphatidylcholine analogue in yeast. J Biol Chem 288(12): 8405-8418, 2013. PMID: 23335509. DOI: $10.1074 /$ jbc.M112.425769

62 Gajate $\mathrm{C}$ and Mollinedo F: Lipid rafts, endoplasmic reticulum and mitochondria in the antitumor action of the alkylphospho- lipid analog edelfosine. Anticancer Agents Med Chem 14(4): 509-527, 2014. PMID: 24628241. DOI: 10.2174/18715206146 66140309222259

63 Carrasco MP, Jiménez-López JM, Ríos-Marco P, Segovia JL and Marco C: Disruption of cellular cholesterol transport and homeostasis as a novel mechanism of action of membranetargeted alkylphospholipid analogues. Br J Pharmacol 160(2): 355-366, 2010. PMID: 20423345. DOI: 10.1111/j.14765381.2010.00689.x

64 Hegedüs L, Padányi R, Molnár J, Pászty K, Varga K, Kenessey I, Sárközy E, Wolf M, Grusch M, Hegyi Z, Homolya L, Aigner C, Garay T, Hegedüs B, Tímár J, Kállay E and Enyedi Á: Histone deacetylase inhibitor treatment increases the expression of the plasma membrane $\mathrm{Ca}^{2+}$ pump PMCA4b and inhibits the migration of melanoma cells independent of ERK. Front Oncol 7: 95, 2017. PMID: 28596940. DOI: 10.3389/fonc.2017.00095

65 Desborough MJR and Keeling DM: The aspirin story - from willow to wonder drug. Br J Haematol 177(5): 674-683, 2017. PMID: 28106908. DOI: 10.1111/bjh.14520

66 Vane JR and Botting RM: The mechanism of action of aspirin. Thromb Res 110(5-6): 255-258, 2003. PMID: 14592543. DOI: 10.1016/s0049-3848(03)00379-7

67 Hundal RS, Petersen KF, Mayerson AB, Randhawa PS, Inzucchi $\mathrm{S}$, Shoelson SE and Shulman GI: Mechanism by which high-dose aspirin improves glucose metabolism in type 2 diabetes. J Clin Invest 109(10): 1321-1326, 2002. PMID: 12021247. DOI: 10.1172/JCI14955

68 Alsop RJ, Toppozini L, Marquardt D, Kučerka N, Harroun TA and Rheinstädter MC: Aspirin inhibits formation of cholesterol rafts in fluid lipid membranes. Biochim Biophys Acta 1848(3): 805-812, 2015. PMID: 25475646. DOI: 10.1016/j.bbamem. 2014.11.023

69 Rumore MM, Aron SM and Hiross EJ: A review of mechanism of action of aspirin and its potential as an immunomodulating agent. Med Hypotheses 22(4): 387-400, 1987. PMID: 2438544. DOI: $10.1016 / 0306-9877(87) 90034-x$

70 Calder PC: Polyunsaturated fatty acids and inflammatory processes: New twists in an old tale. Biochimie 91(6): 791-795, 2009. PMID: 19455748. DOI: 10.1016/j.biochi.2009.01.008

71 Kim JM, Lee KP, Park SJ, Kang S, Huang J, Lee JM, Sato K, Chung HY, Okajima F and Im DS: Omega-3 fatty acids induce $\mathrm{Ca}(2+)$ mobilization responses in human colon epithelial cell lines endogenously expressing FFA4. Acta Pharmacol Sin 36(7): 813-820, 2015. PMID: 26005911. DOI: 10.1038/aps.2015.29

72 Kishi S, Fujiwara-Tani R, Luo Y, Kawahara I, Goto K, Fujii K, Ohmori H, Nakashima C, Sasaki T and Kuniyasu H: Prometastatic signaling of the trans fatty acid elaidic acid is associated with lipid rafts. Oncol Lett 15(4): 4423-4426, 2018. PMID: 29556289. DOI: 10.3892/ol.2018.7817

73 On spirit of turpentine in the yellow fever. Med Phys J 15(83): 16, 1806. PMID: 30491209.

74 Copland A: Memoir on the employment of terebinthinous remedies. Lond Med Phys J 46(270): 185-206, 1821. PMID: 30494333

75 Janero DR and Makriyannis A: Terpenes and lipids of the endocannabinoid and transient-receptor-potential-channel biosignaling systems. ACS Chem Neurosci 5(11): 1097-1106, 2014. PMID: 24866555. DOI: 10.1021/cn5000875

76 Mishra NN, Liu GY, Yeaman MR, Nast CC, Proctor RA, McKinnell J and Bayer AS: Carotenoid-related alteration of cell 
membrane fluidity impacts Staphylococcus aureus susceptibility to host defense peptides. Antimicrob Agents Chemother 55(2): 526-531, 2011. PMID: 21115796. DOI: 10.1128/AAC.00680-10

77 Tapiero H, Townsend DM and Tew KD: The role of carotenoids in the prevention of human pathologies. Biomed Pharmacother 58(2): 100-110, 2004. PMID: 14992791. DOI: 10.1016/ j.biopha.2003.12.006

78 Gruszecki WI and Strzałka K: Carotenoids as modulators of lipid membrane physical properties. Biochim Biophys Acta 1740(2): 108-115, 2005. PMID: 15949676. DOI: 10.1016/j.bbadis. 2004.11.015

79 Hussain SA, Sulaiman AA, Alhaddad H and Alhadidi Q: Natural polyphenols: Influence on membrane transporters. J Intercult Ethnopharmacol 5(1): 97-104, 2016. PMID: 27069731. DOI: $10.5455 /$ jice. 20160118062127

80 Dejani NN, Elshabrawy HA, Bezerra Filho CDSM and de Sousa DP: Anticoronavirus and immunomodulatory phenolic compounds: Opportunities and pharmacotherapeutic perspectives. Biomolecules 11(8): 1254, 2021. PMID: 34439920. DOI: 10.3390/biom11081254

81 Ontiveros M, Rinaldi D, Marder M, Espelt MV, Mangialavori I, Vigil M, Rossi JP and Ferreira-Gomes M: Natural flavonoids inhibit the plasma membrane $\mathrm{Ca}^{2+}$-ATPase. Biochem Pharmacol 166: 111, 2019. PMID: 31071329. DOI: 10.1016/j.bcp.2019.05.004

82 Peter AE, Sandeep BV, Rao BG and Kalpana VL: Calming the storm: Natural immunosuppressants as adjuvants to target the cytokine storm in COVID-19. Front Pharmacol 11: 583777, 2021. PMID: 33708109. DOI: 10.3389/fphar.2020.583777

83 Zhang T, Qiu Y, Luo Q, Zhao L, Yan X, Ding Q, Jiang H and Yang H: The mechanism by which luteolin disrupts the cytoplasmic membrane of methicillin-resistant staphylococcus aureus. J Phys Chem B 122(4): 1427-1438, 2018. PMID: 29309144. DOI: 10.1021/acs.jpcb.7b05766

84 Milardi GL, Stringaro A, Colone M, Bonincontro A and Risuleo $\mathrm{G}$ : The cell membrane is the main target of resveratrol as shown by interdisciplinary biomolecular/cellular and biophysical approaches. J Membr Biol 247(1): 1-8, 2014. PMID: 24166779. DOI: $10.1007 / \mathrm{s} 00232-013-9604-1$

85 Hung WC, Chen FY, Lee CC, Sun Y, Lee MT and Huang HW: Membrane-thinning effect of curcumin. Biophys J 94(11): 43314338, 2008. PMID: 18310254. DOI: 10.1529/biophysj.107.126888

86 Leite NB, Martins DB, Fazani VE, Vieira MR and Dos Santos Cabrera MP: Cholesterol modulates curcumin partitioning and membrane effects. Biochim Biophys Acta Biomembr 1860(11): 2320-2328, 2018. PMID: 29883674. DOI: 10.1016/j.bbamem. 2018.05.018

87 Ingolfsson HI, Koeppe RE 2nd and Andersen OS: Curcumin is a modulator of bilayer material properties. Biochemistry 46(36): 10384-10391, 2007. PMID: 17705403. DOI: 10.1021/bi701013n

88 Liu G, Zhang S, Yang K, Zhu L and Lin D: Toxicity of perfluorooctane sulfonate and perfluorooctanoic acid to Escherichia coli: Membrane disruption, oxidative stress, and DNA damage induced cell inactivation and/or death. Environ Pollut 214: 806-815, 2016. PMID: 27155098. DOI: 10.1016/ j.envpol.2016.04.089

89 O'connor J and Chapin R: Critical evaluation of observed adverse effects of endocrine active substances on reproduction and development, the immune system, and the nervous system. Pure and Applied Chemistry 75(11-12): 2099-2123, 2021. DOI: 10.1351/pac200375112099
90 Calabrese EJ and Baldwin LA: Toxicology rethinks its central belief. Nature 421(6924): 691-692, 2003. PMID: 12610596. DOI: $10.1038 / 421691$ a

91 Vandenberg LN, Colborn T, Hayes TB, Heindel JJ, Jacobs DR Jr, Lee DH, Shioda T, Soto AM, vom Saal FS, Welshons WV, Zoeller RT and Myers JP: Hormones and endocrine-disrupting chemicals: low-dose effects and nonmonotonic dose responses. Endocr Rev 33(3): 378-455, 2012. PMID: 22419778. DOI: 10.1210/er.2011-1050

92 Sargis RM and Simmons RA: Environmental neglect: endocrine disruptors as underappreciated but potentially modifiable diabetes risk factors. Diabetologia 62(10): 1811-1822, 2019. PMID: 31451869. DOI: $10.1007 / \mathrm{s} 00125-019-4940-z$

93 Thomas P and Dong J: Novel mechanism of endocrine disruption by fungicides through binding to the membrane androgen receptor, ZIP9 (SLC39A9), and antagonizing rapid testosterone induction of the intrinsic apoptotic pathway. Steroids 149: 108415, 2019. PMID: 31152826. DOI: 10.1016/j.steroids. 2019.05 .007

94 Zhang X, Yao W, Jia B, Sun D, Ka W, He D, Wang X and Wen $\mathrm{Z}$ : Acute dichlorvos poisoning induces hemorheological abnormalities in rabbits via oxidative stress. Clin Hemorheol Microcirc 44(3): 207-216, 2010. PMID: 20364066. DOI: 10.3233/CH-2010-1264

95 Matsumura F, Brewster DW, Madhukar BV and Bombick DW: Alteration of rat hepatic plasma membrane functions by 2,3,7,8tetrachlorodibenzo-p-dioxin (TCDD). Arch Environ Contam Toxicol 13(5): 509-515, 1984. PMID: 6237620. DOI: 10.1007/ BF01056330

96 Peropadre A, Hazen MJ, Pérez Martín JM and Fernández Freire P: An acute exposure to perfluorooctanoic acid causes nonreversible plasma membrane injury in HeLa cells. Environ Pollut 260: 114008, 2020. PMID: 31995777. DOI: 10.1016/j.envpol. 2020.114008

97 Mancini FR, Cano-Sancho G, Gambaretti J, Marchand P, Boutron-Ruault MC, Severi G, Arveux P, Antignac JP and Kvaskoff M: Perfluorinated alkylated substances serum concentration and breast cancer risk: Evidence from a nested case-control study in the French E3N cohort. Int J Cancer 146(4): 917-928, 2020. PMID: 31008526. DOI: 10.1002/ ijc. 32357

98 Villar-Pazos S, Martinez-Pinna J, Castellano-Muñoz M, AlonsoMagdalena P, Marroqui L, Quesada I, Gustafsson JA and Nadal A: Molecular mechanisms involved in the non-monotonic effect of bisphenol-a on ca ${ }^{2+}$ entry in mouse pancreatic $\beta$-cells. Sci Rep 7(1): 11770, 2017. PMID: 28924161. DOI: 10.1038/s41598-01711995-3

99 Welshons WV, Nagel SC and vom Saal FS: Large effects from small exposures. III. Endocrine mechanisms mediating effects of bisphenol A at levels of human exposure. Endocrinology 147(6 Suppl): S56-S69, 2006. PMID: 16690810. DOI: 10.1210/ en.2005-1159

100 Jurewicz J and Hanke W: Exposure to phthalates: reproductive outcome and children health. A review of epidemiological studies. Int J Occup Med Environ Health 24(2): 115-141, 2011. PMID: 21594692. DOI: 10.2478/s13382-011-0022-2

101 Wang Z, Zhu X, Su Y, Xu W, Liu H, Liu Z, Chen W and Wang J: Dimethyl phthalate damaged the cell membrane of Escherichia coli K12. Ecotoxicol Environ Saf 180: 208-214, 2019. PMID: 31096126. DOI: 10.1016/j.ecoenv.2019.05.009 
102 Clutterbuck H: An inquiry into the seat and nature of fever. Edinb Med Surg J 14(13): 74-81, 1808.

103 Skerritt M: Acute febrile glycosuria. Br Med J 2(1301): 10521053,1885

104 Su HW, Yi YC, Wei TY, Chang TC and Cheng CM: Detection of ovulation, a review of currently available methods. Bioeng Transl Med 2(3): 238-246, 2017. PMID: 29313033. DOI: 10.1002/ btm2.10058

105 Elliot SL, Blanford S and Thomas MB: Host-pathogen interactions in a varying environment: temperature, behavioural fever and fitness. Proc Biol Sci 269(1500): 1599-1607, 2002. PMID: 12184830. DOI: 10.1098/rspb.2002.2067

106 Schieber AM and Ayres JS: Thermoregulation as a disease tolerance defense strategy. Pathog Dis 74(9): ftw106, 2016 PMID: 27815313. DOI: 10.1093/femspd/ftw106

107 Ghio A, Bertolotto A, Resi V, Volpe L and Di Cianni G: Triglyceride metabolism in pregnancy. Adv Clin Chem 55: 133153, 2011. PMID: 22126027. DOI: 10.1016/b978-0-12-387042$1.00007-1$

108 Sonagra AD, Biradar SM, K D and Murthy D S J: Normal pregnancy- a state of insulin resistance. J Clin Diagn Res 8(11): CC01-CC03, 2014. PMID: 25584208. DOI: 10.7860/JCDR/ 2014/10068.5081

109 Liu J, Zeng FF, Liu ZM, Zhang CX, Ling WH and Chen YM: Effects of blood triglycerides on cardiovascular and all-cause mortality: a systematic review and meta-analysis of 61 prospective studies. Lipids Health Dis 12: 159, 2013. PMID: 24164719. DOI: $10.1186 / 1476-511 X-12-159$

110 Yoon JS and Lee HW: Diabetogenic effect of statins: a doubleedged sword? Diabetes Metab J 37(6): 415-422, 2013. PMID: 24404512. DOI: $10.4093 / \mathrm{dmj} .2013 .37 .6 .415$

111 Kahn BB and Flier JS: Obesity and insulin resistance. J Clin Invest 106(4): 473-481, 2000. PMID: 10953022. DOI: 10.1172/JCI10842

112 Van Gaal LF, Zhang A, Steijaert MM and De Leeuw IH: Human obesity: from lipid abnormalities to lipid oxidation. Int J Obes Relat Metab Disord 19 Suppl 3: S21-S26, 1995. PMID: 8581073.

113 Pellini R, Venuti A, Pimpinelli F and Abril E: Obesity may hamper SARS-COV-2 vaccine immunogenicity. MedRXiv, 2021 DOI: $10.1101 / 2021.02 .24 .21251664$

114 Abrams ME, Johnson KA, Perelman SS, Zhang LS, Endapally S, Mar KB, Thompson BM, McDonald JG, Schoggins JW, Radhakrishnan A and Alto NM: Oxysterols provide innate immunity to bacterial infection by mobilizing cell surface accessible cholesterol. Nat Microbiol 5(7): 929-942, 2020 PMID: 32284563. DOI: 10.1038/s41564-020-0701-5

115 Pucadyil TJ and Chattopadhyay A: Role of cholesterol in the function and organization of G-protein coupled receptors. Prog Lipid Res 45(4): 295-333, 2006. PMID: 16616960. DOI: 10.1016/j.plipres.2006.02.002

116 Kumar G, Kumar N, Taneja A, Kaleekal T, Tarima S, McGinley E, Jimenez E, Mohan A, Khan RA, Whittle J, Jacobs E, Nanchal $\mathrm{R}$ and Milwaukee Initiative in Critical Care Outcomes Research (MICCOR) Group of Investigators: Nationwide trends of severe sepsis in the 21st century (2000-2007). Chest 140(5): 1223-1231 2011. PMID: 21852297. DOI: 10.1378/chest.11-0352

117 Zuurbier CJ, Keijzers PJ, Koeman A, Van Wezel HB and Hollmann MW: Anesthesia's effects on plasma glucose and insulin and cardiac hexokinase at similar hemodynamics and without major surgical stress in fed rats. Anesth Analg 106(1):
135-42, table of contents, 2008. PMID: 18165568. DOI: 10.1213/01 ane.0000297299.91527.74

118 Zuurbier CJ, Hoek FJ, van Dijk J, Abeling NG, Meijers JC, Levels JH, de Jonge E, de Mol BA and Van Wezel HB: Perioperative hyperinsulinaemic normoglycaemic clamp causes hypolipidaemia after coronary artery surgery. Br J Anaesth 100(4): 442-450, 2008. PMID: 18305079. DOI: 10.1093/bja/ aen018

119 Bhukal I, Thimmarayan G, Bala I, Solanki SL and Samra T: Comparison of serum triglyceride levels with propofol in long chain triglyceride and propofol in medium and long chain triglyceride after short term anesthesia in pediatric patients. Saudi J Anaesth 8(Suppl 1): S53-S56, 2014. PMID: 25538522. DOI: 10.4103/1658-354X.144076

120 Kotagal M, Symons RG, Hirsch IB, Umpierrez GE, Dellinger EP, Farrokhi ET, Flum DR and SCOAP-CERTAIN Collaborative: Perioperative hyperglycemia and risk of adverse events among patients with and without diabetes. Ann Surg 261(1): 97-103, 2015. PMID: 25133932. DOI: 10.1097/SLA.0000000000000688

121 Donat-Vargas C, Bergdahl IA, Tornevi A, Wennberg M, Sommar J, Kiviranta H, Koponen J, Rolandsson $\mathrm{O}$ and Åkesson A: Perfluoroalkyl substances and risk of type II diabetes: A prospective nested case-control study. Environ Int 123: 390-398, 2019. PMID: 30622063. DOI: 10.1016/j.envint.2018.12.026

122 Nelson JW, Hatch EE and Webster TF: Exposure to polyfluoroalkyl chemicals and cholesterol, body weight, and insulin resistance in the general U.S. population. Environ Health Perspect 118(2): 197-202, 2010. PMID: 20123614. DOI: 10.1289/ehp.0901165

123 Fader KA, Nault R, Ammendolia DA, Harkema JR, Williams KJ, Crawford RB, Kaminski NE, Potter D, Sharratt B and Zacharewski TR: 2,3,7,8-tetrachlorodibenzo-p-dioxin alters lipid metabolism and depletes immune cell populations in the jejunum of C57BL/6 mice. Toxicol Sci 148(2): 567-580, 2015. PMID: 26377647. DOI: $10.1093 /$ toxsci/kfv206

124 Chang JW, Chen HL, Su HJ, Liao PC, Guo HR and Lee CC: Dioxin exposure and insulin resistance in Taiwanese living near a highly contaminated area. Epidemiology 21(1): 56-61, 2010. PMID: 20010210. DOI: 10.1097/EDE.0b013e3181c2fc6e

125 Scheel: Observations on the efficacy of olive oil, for preventing and curing the plague. Med Phys J 6(31): 247-251, 1801. PMID: 30491050

126 Mutoh T, Nishimura R, Kim H, Matsunaga S, Kadosawa T, Mochizuki $M$ and Sasaki N: Rapid inhalation induction of anesthesia by halothane, enflurane, isoflurane and sevoflurane and their cardiopulmonary effects in dogs. J Vet Med Sci 57(6): 1007-1013, 1995. PMID: 8720038. DOI: 10.1292/jvms.57.1007

127 Bonini MG, Stadler K, Silva SO, Corbett J, Dore M, Petranka J, Fernandes DC, Tanaka LY, Duma D, Laurindo FR and Mason RP: Constitutive nitric oxide synthase activation is a significant route for nitroglycerin-mediated vasodilation. Proc Natl Acad Sci USA 105(25): 8569-8574, 2008. PMID: 18562300. DOI: 10.1073/pnas.0708615105

128 Divakaran S and Loscalzo J: The role of nitroglycerin and other nitrogen oxides in cardiovascular therapeutics. J Am Coll Cardiol 70(19): 2393-2410, 2017. PMID: 29096811. DOI: 10.1016/ j.jacc.2017.09.1064

129 Lyons D, Miller MD, Hedgecock-Rowe AA, Crane AM and Porrino LJ: Time-dependent effects of acute ethanol administration on regional cerebral blood flow in the rat. Alcohol 
16(3): 213-219, 1998. PMID: 9744852. DOI: 10.1016/s07418329(98)00005-6

130 Horita A and Weber LJ: Skin penetrating property of drugs dissolved in dimethylsulfoxide (DMSO) and other vehicles. Life Sci (1962) 3: 1389-1395, 1964. PMID: 14248627. DOI: 10.1016/0024-3205(64)90079-7

131 Blanchard OL, Friesenhahn G, Javors MA and Smoliga JM: Development of a lozenge for oral transmucosal delivery of trans-resveratrol in humans: proof of concept. PLoS One 9(2): e90131, 2014. PMID: 24587240. DOI: 10.1371/journal. pone.0090131

$132 \mathrm{Li} \mathrm{SH}$, Tian HB, Zhao HJ, Chen LH and Cui LQ: The acute effects of grape polyphenols supplementation on endothelial function in adults: meta-analyses of controlled trials. PLoS One 8(7): e69818, 2013. PMID: 23894543. DOI: 10.1371/journal. pone.0069818

133 Puskás Z and Schuierer G: Determination of blood circulation time for optimizing contrast medium administration in CT angiography. Radiologe 36(9): 750-757, 1996. PMID: 8999453. DOI: $10.1007 / \mathrm{s} 001170050138$

Received September 3, 2021 Revised September 26, 2021 Accepted September 28, 2021 